УДК 342.365:342.156:342.514

DOI https://doi.org/10.51989/NUL.2021.5.8

\title{
НЕСТОРІАНСЬКИЙ РУХ: ВІД ПОЛІТИЧНОГО ВЧЕННЯ ДО ЮРИДИЧНОЇ ПРАВОСУБ'ЄКТНОСТІ (З ІСТОРИКО-ПРАВОВОЇ СПАДЩИНИ ІРАНО-ВІЗАНТІЙСЬКОГО ПОРУБІЖЖЯ)
}

\author{
Мельник Віктор Мирославович, \\ кандидат політичних наук, \\ головний редактор журналу «Аннали юридичної історії», \\ асистент кафедри політології філософського факультету \\ Київського національного університету імені Тараса Шевченка, \\ викладач кафедри філософії та суспільних наук \\ Вінницького національного медичного університету імені М.I. Пирогова
}

Стаття присвячена важливому питанню історії міжнародної правосуб'єктності - трансформації пізньоантичної єресі несторіан у самостійну та суб'єктну церкву. Як відомо, нині несторіани об'єднані в межах «Ассирійської Церкви Сходу», що охоплює понад 300 тисяч парафіян. Незважаючи на перманентні збройні конфлікти в Сирії й Іраку, «Ассирійська Церква Сходу» залишається дієвим актором як політичного, так і законодавчого процесу. Не можна відкидати значення юридичного спадку несторіанської форми християнства. Поза несторіанством, що із 431 по 484 роки укорінилось у Новоперському царстві династії Сасанідів, складно досліджувати історію держави та права Ірану. Законодавчі практики Східної Римської імперії (Візантії), орієнтовані на заборону діяльності несторіанських екклезій, призвели до формування нової системи церковно-правових норм - антиєретичних приписів. Першим великим антиєретичним Церковним собором став 3'їзд в Ефесі (431 рік). Незважаючи на спроби попередніх Вселенських соборів (325 та 381 роки), тільки Ефеський собор зумів витворити повноцінні норми антиєретичних приписів. Цьому надзвичайно сприяла попередня діяльність константинопольського єпископа Несторія. Серед заслуг цього діяльного сирійця виявилась пропаганда потреби єдиної державноцерковної ідеології. Однак внутрішні інтриги не дали Несторію змоги розвивати власне ідейно-політичне вчення. Несторія засудили на Ефеському соборі «за єресь», сенс якої полягав у визнанні Ісуса Христа «людиною в момент народження». Відкрита боротьба римлян і александрійців проти Несторія автоматично означала протистояння сирійському купецькому лобі, що стояло за єпископом. Рішення Ефеського собору оголошували десятки тисяч сирійців «поза законом», що, зрештою, призвело до масової міграції з території візантійського Близького Сходу. Перська династія Сасанідів радо прийняла біженців із Сирії та дозволила заможним сирійцям заснувати свій особливий Ктесифонський патріархат. У 484 році рішенням Бет-Лапатського собору цей патріархат було конституйовано на державно-правовому рівні. Із 484 по 651 роки Ктесифонський патріархат залишався складовою частиною державного апарату Персії. Надалі, після ісламського завоювання Ірану, саме Ктесифонський патріархат перетворився на «Ассирійську Церкву Сходу». Однак тут важливо усвідомити: забороняючі канони римсько-візантійського права ніколи та ніким не скасовувались. Вони й досі діють. У статті акцентується на таких актуальних документах: рішеннях Третього вселенського сбору в Ефесі (431 рік), рішеннях Четвертого вселенського собору в Халкедоні (451 рік), Указі східноримського імператора Зенона Ісавра (489 рік).

Ключові слова: міжнародна правосуб'єктність, римське право, канонічне право, церковне право, Східна Римська імперія (Візантія), Новоперське царство, Ассирійська Церква Сходу, несторіанство.

Melnyk Viktor. Nestorianism: from political doctrine to the legal personality (some legal aspects of the Iranian-Byzantine border heritage)

The article is devoted to important canonic issues in the history of international legal personality. The special description is dedicated to the transformation of the late antique heresy of Nestorianism into a separate Church. As we know, today the Nestorians are united within the "Assyrian Church of the East", which includes more than 300 thousand parishioners. Despite 
the ongoing conflicts in Syria and Iraq, the "Assyrian Church of the East" remains an effective actor in political and legislative processes. The significance of the legal heritage of the Nestorian form of Christianity cannot be ruled out. It is important to understand that it's impossible to study the history of the state and law of Iran without Nestorianism. Similarly, the legislative practices of the Eastern Roman Empire (Byzantium), aimed at banning the activities of the Nestorian ecclesia, led to the formation of a new system of ecclesiastical law - anti-heretical precepts. The first great anti-heretical Council of the Church was the Ephesus Council (431 AD). Despite the attempts of previous Ecumenical Councils (325 AD and 381 AD), only the Ephesus Council was able to create full-fledged norms of anti-heretical precepts. This was greatly facilitated by the previous activities of Constantinople Bishop Nestorius. However, internal intrigues didn't allow Nestorius to develop his own ideological and political doctrine. Nestorius was condemned at the Ephesus Council "for heresy". In Ephesus Council opinion, his main mistake was the recognition of Jesus Christ as "a Man at Birth". The open struggle of the Romans and Alexandrians against Nestorius automatically meant opposition to the Syrian merchant lobby, which stood behind the bishop. The tens of thousands of Syrians were declared "illegal" by the decisions of the Ephesus Council. These decisions led to mass migration from the territory of the Byzantine Middle East. The Sassanid Persian dynasty welcomed refugees from Syria and allowed wealthy Syrians to establish their own special Ctesiphon Patriarchate. By the decision of the Beth Lapat Council, this patriarchate was constituted at the legal level. From 484 AD to 651 AD, the Ctesiphon Patriarchate remained part of the Persian state apparatus. Later, after the Islamic conquest of Iran, this Ctesiphon Patriarchate was restored in the "Assyrian Church of the East". However, it is important to realize here that the prohibitory canons of Roman-Byzantine law were never abolished by anyone. These documents still work. This article focuses on the following relevant documents: the decisions of the Third Ecumenical Council in Ephesus (431), the decisions of the Fourth Ecumenical Council in Chalcedon (451), the decrees of the Eastern Roman Emperor Zeno (489).

Key words: International Legal Personality, Roman Law, Canon Law, Ecclesiastical Law, Eastern Roman Empire (Byzantium), Persian Kingdom of Kingdoms, Assyrian Church of East, Nestorianism.

У справі інтегративного розуміння правової природи християнства, безсумнівно, найбільше еволюціонувала Римська імперія, де після реформ 313-395 рр. кафолична й ортодоксальна Християнська Віра стала єдиною офіційною релігією [3]. Решта вірувань не заборонялися і навіть захищалися державою, але формально не мали права публічної підтримки (передусім говоримо про традиційні форми політеїзму в сільській місцевості та поширений серед купецтва іудаїзм).

Засвоїмо зауваження Льва Гумільова: «Християнська релігійна думка із самого моменту свого виникнення розтеклася на безліч потоків, з яких більша частина висохла, але деякі стали річками» [2, с. 47]. Потоком, спершу перекритим духовенством Константинополя й Риму, що перетворився на найбільш бурхливу політико-правову річку, виявилось несторіанство - потужна єретична рефлексія на ґрунті ортодоксального християнства.

Його формальним засновником уважається єпископ Несторій (381-451 рр.), що народився в Цезарії Германікейській (на річці Євфрат). Предки Несторія - асси- рійці, які мігрували з Парфянського Ірану на римський бік Месопотамії. Отримавши чудову освіту в Афінській і Антіохійській школах, прослухавши лекції провідних богословів візантійського Сходу й Еллади, Несторій прославився в ораторських змаганнях і здобув запрошення прибути у столицю, де 10 квітня 428 р. став архієпископом Нового Риму (Константинополя) та, відповідно, вищим придворним радником імператора Феодосія II Законодавця (408-450 pp.) [3; 10].

Несторій радив Феодосію централізувати ортодоксальну церкву й ліквідувати на законодавчому рівні всі неканонічні течії, що заперечували або критикували Нікейський Символ Віри, затверджений як основа Христової Церкви на Нікейському вселенському церковному соборі (325 р.).

Тільки за наявності централізованої церкви, як слушно вважав Несторій, така велика та різноплемінна держава, як Римська імперія здатна перемогти водночас дві великі сили - східноєвропейських кочівників (тоді - гунів) на дунайському лімесі і Сасанідський Іран у Месопотамії та Вірменії. Окрім того, єдина віра, на 
думку Несторія, уродженця Близького Сходу, повинна була допомогти Риму опанувати племена Аравії й Ефіопії. Щоби місіонерським чином розповсюджувати Слово Боже на Схід, церква потребувала ідеологічної єдності. Несторію, зокрема, приписують такі слова: «Цезарю, ти мусиш знищити єретиків разом зі мною, і тоді ми разом переможемо персів». Йому ж приписують підпал аріанської церкви в Константинополі та навіть організацію аріанських погромів у новоримській єпархії. Відомо принаймні про заборону, накладену Несторієм на використання священницьких кафедр для демонстрації розважальних вистав [3].

Головний крок, яким Несторій по-справжньому запам'ятався нащадкам, відбувся у філософсько-богословській площині. Несторій висунув філософське обґрунтування тези, обстоюваної прихильниками богослова Фотина Сірмійського з Нижньої Паннонії: термін «Богородиця» щодо Пресвятої Діви Марії некоректний. Фотин стверджував, що насправді необхідно вживати поняття «Людинородиця» у літургії [10].

В авторських проповідях Несторія «Людинородиця» паннонських послідовників Фотина поступово трансформувалася в більш нейтральну «Христородицю». Несторій проголошував, що Ісус Христос володів як божественною, так і людською природами. На думку єпископа, Христос - це тілесне «вмістилище» та «храм» для Вищої Божественної Сутності. Саме це твердження Несторію поставив у провину Римський помісний собор, засудивши його вчення $з$ усією суворістю та рішучістю першохристиянських часів, діючи в тісній кооперації із кліром антинесторіанського Александрійського Патріархату $[1 ; 9 ; 10]$.

У відповідь на інтриги Риму й Александрії, для розгляду й аналізу так званої «єресі Несторія» імператор зібрав Третій Ефеський вселенський церковний собор (431р.). Важливо, що Феодосій Законодавець обрав Ефес як місце проведення Собору, оскільки саме тут Пресвята Богородиця прожила останні роки свого життя.

Перші шість правил Ефеського собору стосувалися засудження архієпископа Несторія як «нового Іуди», позбавлення його сану і вигнання із церкви. Окрім того, на соборі ухвалювалося важливе рішення: «Єпископ, що проповідує іншу віру, крім Нікейської, позбавляється єпископства, а мирянин виганяється із Церкви. Той, хто, окрім віри, складеної Святими Отцями, які зібралися в Нікеї, пропонує інший нечестивий символ на розбещення та на згубу звернених до пізнання істини з еллінства та юдейства або від якої 6 то не було єресі, якщо мирянин - повинен бути підданий анафемі, а якщо єпископ або клірик - повинен бути позбавлений єпископства і служіння у клірі». Несторій, цілком закономірно, проганявся з Константинопольської єпископської кафедри. Окрім того, його погляди оголошувались незаконними в межах Римської імперії. До вигнання де-факто засуджувались тисячі послідовників Несторія, які жили в багатьох римсько-візантійських провінціях від Нижньої Паннонії до Ассирії. Важливо не забувати: Несторій особисто не емігрував, провівши в оазисі Ібіс (провінція Єгипет) решту життя (помер у 451 р.) [3].

Оскільки Несторій був сирійцем за походженням, здобував свою першу славу в межах канонічної території Антіохійського патріархату, то й прихильників найбільше він мобілізував серед одноплемінників. Більшість у потоці «несторіанської міграції» 430-х рр. за межі Римської імперії становили мешканці близькосхідних провінцій. Закономірним пунктом призначення для цієї міграції виявився ворожий Константинополю Іран [2; 10].

Розуміючи, що несторіани внаслідок ескалації релігійного протистояння всередині Візантії ніяк не можуть бути візантійськими шпигунами, з огляду на можливість їхнього використання в антиримській пропаганді, сасанідські імператори («шахіншахи») Бахрам V (421-439рр.) та Єздигерд II (439-457 рр.) проголосили на теренах Ераншахру «правовий режим релігійної толерантності». У відповідь несторіанські купці вклали значні капітали у зміцнення влади династії Сасанідів, ставши після 431 р. традиційною та формалізованою фінансовою елітою Новоперсидського царства $[2 ; 7 ; 8 ; 10]$.

Сирія з ассирійських часів жила купецтвом і посередництвом у караванній торгівлі [5]. Майже всі сирійські прихильники Несторія володіли пристойними капіта- 
лами, які дозволяли не лише брати участь у громадському житті східних окраїн Візантії, але й швидко реагувати на трансформації мінливої доби. Втрата діяльних купців та підпорядкованої їхнім фінансам громадської думки негативно позначилась на всій подальшій сирійській політиці Східної Римської імперії [7, с. 113-119].

у484p. адепт Несторія БарСаума отримав від шахіншаха Балаша (484-488 рр.) царський Рескрипт про прихильність до несторіан. Незадовго до публікації Рескрипту священник Бар Саума забезпечив стовідсоткову підтримку узурпації влади Балашом із боку найбагатших несторіанських купців [8; 10]. У 484 р. єпископ Бар Саума очолив Царський Перський Синод у БетЛапаті, наділений статусом Всеперського церковного собору. Цей перший «загальноазіатський Собор Християн» ухвалив два доленосні рішення.

По-перше, усі ортодоксальні християнські громади, які розташовувались поза межами Римської імперії, але де-юре належали Антіохійському патріархату та перебували під офіційним захистом східноримського імператора, насильно наверталися в несторіанство і повинні були підкоритися єдиному «Патріарху Персії».

По-друге, шахіншах

Балаш (484-488 рр.), з метою приниження східноримського імператора Зенона Ісавра (476-491 рр.), проголошувався «повноправним захисником християн» та «володарем Християнського Світу».

Дуже цікаво, що рішення Бет-Лапатського собору з'явились саме в 484-487 рр., коли Зенон Ісавр не мав можливості реагувати на ідейно-політичні диверсії персів. У Східній Римській імперії тривала громадянська війна, германці бунтували в західних провінціях. Прикметно: шахіншах Персії затвердив усі рішення Собору негайно і проголосив реформоване Бар Саумом вчення Несторія «другою за значенням дозволеною вірою Персії після зороастризму». Таким чином перський шахіншах розраховував не тільки здобути прихильність фінансової несторіанської еліти Ірану, але й юридично обґрунтувати свої претензії на колишні ахеменідські й селевкідські провінції Близького Сходу та Малої Азії [8].

Бет-Лапатський собор створив у межах Новоперсидського царства повноцінний діофізитський патріархат, згодом трансформований у так званий «Ктесифонський патріархат» (499р.), перетворений пізнішими канонами на «Святу Апостольську Соборну (Кафоличну) Ассирійську Церкву Сходу» [10].

Оновлена діофізитська доктрина цієї «Ассирійської Церкви Сходу» писалася «за мотивами» ідей Несторія патріархом Мар Бабаєм Великим (роки патріархії: 609-628 рр.) уже наприкінці правління Сасанідів. Унаслідок природної схильності нащадків давньосирійського купецтва до соціальної адаптації Ассирійська Церква Сходу існує й донині, контролює понад 300 тис. парафіян із різних областей Сирії, Іраку, Ірану. Зауважимо, що статус архієпископства у складі Ктесифонського патріархату рішеннями Бет-Лапатського Собору 484 р. отримала також давня Мервська єпархія (сучасний Туркменістан), заснована християнськими мандрівниками ще у III ст.i! Саме очолювана мервським купецтвом Маргіанська оаза виявилась потужним центром ранньосередньовічної несторіанізації Хорезму й Согдіани [6].

у 489 р. імператор Зенон Ісавр (476-491 рр.) закрив останню візантійську школу, де ритори та богослови все ще викладали канони несторіанського вчення (у сирійській Едесі), повторно оголосивши несторіан «порушниками закону», підданими анафемі на території всіх провінцій імперії [2, с. 50-51]. Отже, несторіанство засуджувалося та заборонялося нормативно-правовими актами трьох вселенських інституцій:

- рішеннями Третього вселенського coбopy в Ефесі (431р.);

- рішеннями Четвертого вселенського собору в Халкедоні (451р.);

- Указом східноримського імператора Зенона Ісавра (489р.).

Як можна здогадатися, нині вказані рішення не скасовані та продовжують діяти в канонічно-правовому полі [4] як православних патріархатів, так і римського папства.

Так чи інакше, але саме Третій вселенський собор в Ефесі підштовхнув сирійських християн до міграції в Іран та спонукав перських шахіншахів заснувати Ктесифонський патріархат. Формування власної церковно-політичної 
організації сприяло кристалізації центральноазійського християнства як самостійного явища. 3 юридичного погляду йдеться про творення окремої системи церковного та канонічного права, де Ісус Христос визнавався «цінним як людина». Щоправда, усвідомлюючи потребу комунікації 3 халкедонськими церковними інституціями, патріарх Мар Бабай Великий особисто відредагував трактати представників антіохійської богословської школи. Після 628 р., в умовах арабської агресії проти Персії та Константинополя, Ктесифонський патріархат повернувся до проголошення «Боголюдської при- роди Христа». Саме така канонічно-правова позиція дозволила в 1997 р. послам «Ассирійської Церкви Сходу» спробувати налагодити стосунки з халкедонськими церквами. Нині зняття анафеми відбулось лише в односторонньому порядку. Несторіанський клір більше не вважає православні й католицький патрірхати ворожими, але не має остаточного прийняття з їхнього боку. Водночас норми Ефеського собору чинні. Очевидно, що їхнє скасування вимагає якщо не соборних, то принаймні синодальних рішень патріарших престолів давніх і новітніх халкедонських патріархатів.

\section{ЛITEPATУPA:}

1. Болотов В.В. История Церкви в период Вселенских соборов. Москва : Поколение, 2007. 720 с.

2. Гумилев Л.Н. В поисках вымышленного царства. Санкт-Петербург : Азбука, 2014. 480 с.

3. Дворкин А.Л. Очерки по истории Вселенской Православной Церкви : Курс лекций. Нижний Новгород : Христианская библиотека, 2016. 1024 с.

4. Ерде Петер. Церковне конституційне право. Львів : Свічадо, 1998. 156 с.

5. Крижанівський О.П. Історія стародавнього Сходу. Київ : Либідь, 2009. 592 с.

6. Мамбеталиев А.Э. След Христа на шелковом пути. Bishkek : Janyzak Print, 2013. 53 с.

7. Мельник В.М. Церковно-политический сепаратизм в пределах юго-восточной Византии: публично-правовой контекст (553-564 гг.). Актуальні проблеми держави і права. 2020. Вип. 87. С. 113-119.

8. Периханян А.Г. Общество и право Ирана в парфянский и сасанидский периоды. Москва : Наука, 1983. 384 с.

9. Сидоров А.И. Некоторые проблемы ранневизантийской философии. Древнейшие государства на территории СССР : Материалы и исследования за 1985 г. Москва : Наука, 1986. C. 206-219.

10. Sabo Theodore. From Monophysitism to Nestorianism: AD 431-681. Newcastle upon Tyne : Cambridge Scholars Publishing, 2018. IX + 135 p. 